\title{
Evaluating distal renal tubular acidification function in primary hyperparathyroidism and its effects on bone mineral density
}

\author{
Wangna Tang, Hongwei Jia, Baoping Wang, Yun Chai, Tong Liu, Hao Wang and Chenlin Dai (D)
}

\begin{abstract}
Background: Primary hyperparathyroidism (PHPT) is a common endocrinopathy that may increase fracture risk and decrease bone mineral density (BMD). Some patients develop distal renal tubular acidification dysfunction under conditions of hyperchloraemia or hyperchloraemic acidosis. To examine whether this dysfunction influences the clinical outcome, we explored the distal renal tubular acidification function in patients with PHPT and its effects on the clinical manifestations of the disease.

Methods: We retrospectively analysed 75 PHPT patients with regard to renal tubular acidification and blood gas analysis. The patients were divided into two groups, the renal tubular acidification dysfunction group and normal function group.

Results: Serum phosphate level and total hip bone density were significantly decreased and 25OHD level was significantly increased in the renal tubular acidification dysfunction group in comparison to the normal function group. Female patients in the renal tubular acidification dysfunction group showed significantly decreased femoral neck and total hip BMD and increased susceptibility to fracture. However, there were no such differences in male patients between the two groups.

Conclusions: About $54.6 \%$ of PHPT patients in our study population had abnormal distal renal tubular acidification. PHPT patients with abnormal distal renal tubular acidification may have lower hip bone density. Female PHPT patients with abnormal distal renal tubular acidification showed increased susceptibility to fractures and the development of osteoporosis.
\end{abstract}

Keywords: Primary hyperparathyroidism, Distal renal tubule, Acidification function, Bone mineral density

\section{Background}

Chronic acid retention may decrease bone mineral density (BMD). Studies [1,2] showed that dysfunction of distal renal tubular acidosis may cause bone loss. Patients with abnormal distal renal tubular acidification may not manifest in significant systemic acidosis, however, the increased of acid loading may trigger the release of alkali

\footnotetext{
* Correspondence: daiandzhang@sina.com

Endocrinology and Metabolism Disease Department, Tianjin Medical University General Hospital, 154\# Anshan Road, Heping District, 300052 Tianjin, China
}

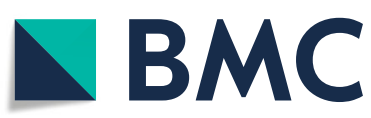

C C The Author(s). 2021 Open Access This article is licensed under a Creative Commons Attribution 4.0 International License, which permits use, sharing, adaptation, distribution and reproduction in any medium or format, as long as you give appropriate credit to the original author(s) and the source, provide a link to the Creative Commons licence, and indicate if changes were made. The images or other third party material in this article are included in the article's Creative Commons licence, unless indicated otherwise in a credit line to the material. If material is not included in the article's Creative Commons licence and your intended use is not permitted by statutory regulation or exceeds the permitted use, you will need to obtain permission directly from the copyright holder. To view a copy of this licence, visit http://creativecommons.org/licenses/by/4.0/ The Creative Commons Public Domain Dedication waiver (http://creativecommons.org/publicdomain/zero/1.0/) applies to the data made available in this article, unless otherwise stated in a credit line to the data.

in the bone, resulting a greater absorption of bone [3]. Sromicki et al. reported that $23 \%$ of osteopoenia/osteoporosis patients may have abnormal distal renal tubular acidification, which may lead to chronic acid retention [4]. Primary hyperparathyroidism (PHPT) is the third most common endocrine disease. Although the incidence of proximal renal tubular acidification dysfunction is known to be higher in PHPT patients, there have been few studies regarding distal renal tubular acidification dysfunction in PHPT [5-7]. Therefore, the aim of the retrospective study was to explore distal renal 
tubular acidification function in PHPT patients and to examine its potential impact on bone and whether it affects the clinical presentation.

\section{Methods \\ Subjects}

The study population consisted of 75 patients, 21 men aged 36-74 years and 54 women aged $29-83$ years, with a diagnosis of PHPT [8] according to the following criteria: (1) increased serum calcium above the upper limit of normal range of $2.55 \mathrm{mmol} / \mathrm{L}$, excluding other causes of hypercalcemia; (2) increased PTH above the upper limit of normal range of $7.63 \mathrm{pmol} / \mathrm{L}$; (3) decreased serum phosphorus; and (4) combined with clinical symptom and characteristic radiographic features. The exclusion criteria were as following: patients with multiple endocrine adenoma, secondary or tertiary hyperparathyroidism were excluded from this study. All subjects were hospitalized patients first treated in Tianjin Medical University General Hospital between 2013 and 2019.

Level of Evidence: III,retrospective study.

\section{Methods}

Blood and 24-hour urine electrolytes, kidney and liver function, parathyroid hormone, 25OHD and bone turnover indices were determined. PTH, 25OHD and bone turnover indices were detected by electrochemiluminescence assay in the center laboratory of the hospital. Blood gas analysis and renal tubular acidification were done at the same day. Fasting morning urine was collected and acidification function was determined by the method of titration in an automatic potentiometric $\mathrm{Ti}$ trator. BMD was measured using a bone densitometer (Lunar Prodigy; GE Healthcare, Waukesha, WI, USA). All patients underwent abdominal and parathyroid ultrasonography. Parathyroid lesions were confirmed by enhanced computed tomography $(\mathrm{CT})$ and radionuclide examination. X-ray examinations of the vertebrae, pelvis, skull and hands were performed in almost all patients. The radiologist reviewed the $\mathrm{x}$-rays to issue the reports. The diagnosis of fragile fractures was based on the $\mathrm{x}$ rays reports and patient's medical history.

Subjects were divided into the renal tubular acidification dysfunction group and normal function group based on urinary $\mathrm{pH}>5.8$, decreased ammonium ion (normal range $25.84-200 \mathrm{mmol} / \mathrm{L}$ ) and decreased titratable acid (TA) (normal range 9.57-150 mmol/L) in second morning urine collected after a 12-hour fast. Patients with acute renal dysfunction were excluded from analysis. Acute renal dysfunction [9] is defined as any of the following (Not Graded):increase in SCr by $\geq 0.3 \mathrm{mg} / \mathrm{dl}$ ( $\geq$ $26.5 \mathrm{umol} / \mathrm{l}$ ) within 48 hours; or increase in $\mathrm{SCr}$ to $\geq 1.5$ times baseline, which is known or presumed to have occurred within the prior 7 days; or Urine volume < $0.5 \mathrm{ml} / \mathrm{kg} / \mathrm{h}$ for 6 hours.

Diagnosis of osteoporosis [10] was based on one or more of the following criteria: (1) fragile fracture of the hip or vertebral body; (2) A value for BMD $2.5 \mathrm{SD}$ or more below the young adult mean (T-score $\leq-2.5$ ); (3) BMD measurement showing low bone mass $(-2.5<\mathrm{T}<$ $-1.0)$ and fragile fractures of the proximal humerus, pelvis or distal forearm. T-scores are used in postmenopausal women and men aged 50 years or more. For the other populations, Z-scores or fracture risk are considered.

The study was approved by the Institutional Review Board (IRB)/Ethical Committee of Tianjin Medical University General Hospital.

\section{Statistical methods}

Data were analysed using SPSS 25.0 (SPSS, Chicago, IL, USA). The results are presented as the mean \pm SD. Analysis of the categorical variables was performed by $x^{2}$ or Fisher's test, and comparisons between the two groups were performed using the independent samples $t$ test. The continuous variables of non-normal distribution expressed by M (P25, P75) and the non-parametric test were used for comparisons between the groups. In all analyses, $P<0.05$ was taken to indicate statistical significance.

\section{Results}

Gender distribution, age, BMI, course of disease, blood gas analysis indicators, bone turnover indicators, AKP, blood and urine electrolytes (except serum phosphate) were not significantly different between the renal tubular acidification dysfunction group and normal function group. Urine $\mathrm{PH}$ was significantly increased, urine ammonium ion and titratable acid were significantly decreased in renal tubular acidification dysfunction group $(P<0.01)$. Serum phosphate was significantly decreased and 25OHD was significantly increased in the renal tubular acidification dysfunction group compared with the normal function group $(P<0.05)$. The renal tubular acidification dysfunction group showed decreased serum potassium level and increased parathyroid hormone (PTH) level but these differences were not significant (both $P>0.05$ ). There were no differences in the incidence of kidney stones and fractures between the renal tubular acidification dysfunction group and the normal function group (both $P>0.05$ ). (Table 1).

Total hip BMD was significantly decreased in the renal tubular acidification dysfunction group compared with the normal function group $(P<0.05)$. There were no differences in the proportions of patients with osteoporosis at any site between the two groups $(P>0.05)$. (Table 2$)$. 


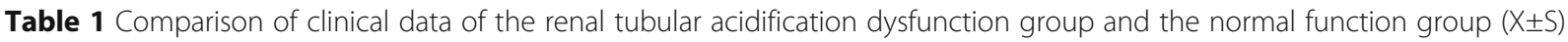

\begin{tabular}{|c|c|c|c|}
\hline Variable & $\begin{array}{l}\text { Abnormal acidification group } \\
\text { (41) }\end{array}$ & $\begin{array}{l}\text { Normal acidification function group } \\
\text { (34) }\end{array}$ & $\mathbf{P}$ \\
\hline Sex (male/female) & $13 / 28$ & $8 / 26$ & $0.432\left(x^{2}\right)$ \\
\hline Medical history (y) & $0.25(1,5.5)$ & $0.33(1,5)$ & $\begin{array}{l}0.881 \text { (Non- } \\
\text { parametric) }\end{array}$ \\
\hline Age, y & $61.1 \pm 12.0$ & $56.8 \pm 11.0$ & 0.116 \\
\hline $\mathrm{BMI}, \mathrm{kg} / \mathrm{m}^{2}$ & $24.2 \pm 4.85$ & $24.74 \pm 3.84$ & 0.602 \\
\hline Albumin, $g / L$ & $41.24 \pm 3.86$ & $40.79 \pm 3.54$ & 0.604 \\
\hline $\begin{array}{l}\text { Albumin-corrected serum calcium, mmol/ } \\
L\end{array}$ & $2.80 \pm 0.39$ & $2.84 \pm 0.31$ & 0.635 \\
\hline Serum phosphate, mmol/L & $0.69 \pm 0.17$ & $0.79 \pm 0.18$ & 0.017 \\
\hline Serum potassium, mmol/L & $3.85 \pm 0.50$ & $4.08 \pm 0.51$ & 0.061 \\
\hline Serum chloride (mmol/L) & $107.55 \pm 3.45$ & $107.23 \pm 3.99$ & 0.717 \\
\hline Serum sodium (mmol/L) & $141.06 \pm 2.70$ & $142.24 \pm 1.71$ & 0.062 \\
\hline Serum magnesium (mmol/L) & $0.83 \pm 0.11$ & $0.86 \pm 0.07$ & 0.220 \\
\hline Serum creatinine, umol/L & $58(47.5,73)$ & $58(42.75,73.25)$ & $\begin{array}{l}0.447 \text { (Non- } \\
\text { parametric) }\end{array}$ \\
\hline $\operatorname{AkP}(U / L)$ & $125(91.5,231.5)$ & $103.5(67,157.75)$ & $\begin{array}{l}0.075 \text { (Non- } \\
\text { parametric) }\end{array}$ \\
\hline PTH (pmol/L) & $59.4(24.65,130)$ & $36.1(17.17,64.02)$ & $\begin{array}{l}0.061 \text { (Non- } \\
\text { parametric) }\end{array}$ \\
\hline 25OHD (nmol/L) & $34.5(21.4,64.02)$ & $25.5(20.45,32.66)$ & $\begin{array}{l}0.020 \text { (Non- } \\
\text { parametric) }\end{array}$ \\
\hline Urine PH (4.5-6.5) & $6.67 \pm 0.45$ & $5.78 \pm 0.42$ & 0.000 \\
\hline Urine $\mathrm{HCO}^{-}(0-12.44 \mathrm{mmol} / \mathrm{L})$ & $5.50(3.35,10.90)$ & $4.50(2.87,5.90)$ & $\begin{array}{l}0.231 \text { (Non- } \\
\text { parametric) }\end{array}$ \\
\hline Urine TA (9.57-150mmol/L) & $4.45 \pm 2.83$ & $11.91 \pm 4.39$ & 0.000 \\
\hline Urine $\mathrm{NH}^{+}(25.84-200 \mathrm{mmol} / \mathrm{L})$ & $16.48 \pm 5.57$ & $25.62 \pm 5.89$ & 0.000 \\
\hline Blood gas PH (7.35-7.45) & $7.40 \pm 0.28$ & $7.40 \pm 0.21$ & 0.266 \\
\hline PCO2 (mmHg) & $36.76 \pm 5.12$ & $37.51 \pm 4.84$ & 0.519 \\
\hline HCO3-(mmol/L) & $23.20 \pm 3.15$ & $23.87 \pm 2.63$ & 0.327 \\
\hline $\mathrm{BE}(\mathrm{mmol} / \mathrm{L})$ & $-1.80(-3.3,0.82)$ & $-0.77(-1.92,1.00)$ & $\begin{array}{l}0.165 \text { (Non- } \\
\text { parametric) }\end{array}$ \\
\hline Urinary calcium, (mmol/24h) & $8.30 \pm 3.30$ & $7.98 \pm 3.64$ & 0.280 \\
\hline Urinary phosphate, (mmol/24h) & $18.8 \pm 7.34$ & $20.4 \pm 8.34$ & 0.389 \\
\hline Urinary potassium, (mmol/24h) & $18.65 \pm 7.11$ & $20.40 \pm 8.34$ & 0.331 \\
\hline Urine sodium (mmol/24h) & $138.46(93.01,205.75)$ & $197.6(157.59,228.51)$ & $\begin{array}{l}0.161 \text { (Non- } \\
\text { parametric) }\end{array}$ \\
\hline Urine magnesium (mmol/24h) & $2.85(1.84,3.63)$ & $2.7(2.19,3.48)$ & $\begin{array}{l}0.898 \text { (Non- } \\
\text { parametric) }\end{array}$ \\
\hline OC (ng/ml) & $60.06(29.49,125.25)$ & $59.61(33.58,131.30)$ & $\begin{array}{l}0.903 \text { (Non- } \\
\text { parametric) }\end{array}$ \\
\hline CTX (ng/ml) & $0.99(0.65,1.86)$ & $1.18(0.80,2.49)$ & $\begin{array}{l}0.225 \text { (Non- } \\
\text { parametric) }\end{array}$ \\
\hline PINP (ng/ml) & $70(45.28,125.25)$ & $74.28(41.09,103.80)$ & $\begin{array}{l}0.709 \text { (Non- } \\
\text { parametric) }\end{array}$ \\
\hline Kidney stones (with/without) & $19 / 22$ & $12 / 22$ & $0.333\left(x^{2}\right)$ \\
\hline Fracture (with/without) & $13 / 28$ & $10 / 24$ & $0.830\left(x^{2}\right)$ \\
\hline
\end{tabular}


Table 2 Comparison of bone mineral density in the renal tubular acidification dysfunction group and the normal function group $(\mathrm{X} \pm \mathrm{S})$

\begin{tabular}{llll}
\hline Variable (BMD) & Distal renal tubular dysfunction group & Distal renal tubular normal group & $\mathbf{P}$ \\
\hline $\mathrm{L} 1-\mathrm{L} 4\left(\mathrm{~g} / \mathrm{cm}^{2}\right)$ & $0.837 \pm 0.206$ & $0.923 \pm 0.210$ & 0.166 \\
Femoral neck $\left(\mathrm{g} / \mathrm{cm}^{2}\right)$ & $0.661 \pm 0.173$ & $0.727 \pm 0.130$ & 0.112 \\
Total hip $\left(\mathrm{g} / \mathrm{cm}^{2}\right)$ & $0.676 \pm 0.177$ & $0.770 \pm 0.139$ & 0.030 \\
Osteoporosis at any site $(\mathrm{n}, \%)$ & $23(62.1 \%)$ & $11(44 \%)$ & $0.159\left(\mathrm{X}^{2}\right)$ \\
\hline
\end{tabular}

On stratification according to sex, serum phosphate level, femoral neck and total hip BMD were significantly decreased, while the proportion of patients with bone fractures and osteoporosis at any site were significantly increased in female patients in the renal tubular acidification dysfunction group compared with the normal function group. However, there were no such differences in male patients between the two groups. The comparison of the other parameters between the two groups was the same as before the gender stratification. (Tables 3 and 4)

\section{Discussion}

Abnormal renal tubular acidosis may affect bone metabolism. Results of former study [3] showed that patients with abnormal distal renal tubular acidification may not manifest in significant systemic acidosis, this persistent acid load may trigger the release of the alkali in the bone, resulting in greater bone loss. Other study found that patients with osteoporosis or reduced BMD have a strong relationship with incomplete distal renal tubular acidosis [11] .It has been reported that patients with PHPT are prone to renal tubular dysfunction $[12,13]$.

Table 3 Comparison of bone mineral density between female patients in the renal tubular acidification dysfunction group and the normal function group $(X \pm S)$

\begin{tabular}{|c|c|c|c|}
\hline & $\begin{array}{l}\text { Distal renal tubular dysfunction group } \\
\text { (28) }\end{array}$ & $\begin{array}{l}\text { Distal renal tubular normal group } \\
\text { (26) }\end{array}$ & $\mathbf{P}$ \\
\hline Age, y & $60.21 \pm 13.4$ & $57.6 \pm 11.2$ & 0.436 \\
\hline BMI $\left(\mathrm{kg} / \mathrm{m}^{2}\right)$ & $23.82 \pm 5.16$ & $24.19 \pm 3.93$ & 0.770 \\
\hline Premenopausal/postmenopausal & $4 / 24$ & $3 / 23$ & 0.112 \\
\hline Albumin, $g / L$ & $40.89 \pm 4.11$ & $40.50 \pm 3.56$ & 0.710 \\
\hline $\begin{array}{l}\text { Albumin-corrected serum calcium, } \\
\mathrm{mmol} / \mathrm{L}\end{array}$ & $2.80 \pm 0.42$ & $2.85 \pm 0.31$ & 0.615 \\
\hline Serum phosphate, mmol/L & $0.71 \pm 0.19$ & $0.82 \pm 0.18$ & 0.034 \\
\hline Serum sodium (mmol/L) & $140.92 \pm 3.05$ & $141.7 \pm 2.63$ & 0.371 \\
\hline Serum magnesium (mmol/L) & $0.81 \pm 0.12$ & $0.86 \pm 0.08$ & 0.149 \\
\hline PTH (pmol/L) & $64.9(25.1,145.25)$ & $30.15(18.95,65.92)$ & $\begin{array}{l}0.083 \text { (Non- } \\
\text { parametric) }\end{array}$ \\
\hline $25 \mathrm{OHD}(\mathrm{nmol} / \mathrm{L})$ & $29.5(20.4,41.8)$ & $24.99(20.23,32.61)$ & $\begin{array}{l}0.272 \text { (Non- } \\
\text { parametric) }\end{array}$ \\
\hline Urinary calcium, mmol/24h & $8.01 \pm 3.13$ & $9.86 \pm 6.21$ & 0.169 \\
\hline Urinary phosphate, $\mathrm{mmol} / 24 \mathrm{~h}$ & $17.84 \pm 6.15$ & $19.51 \pm 8.85$ & 0.421 \\
\hline Urine sodium (mmol/24h) & $159.12(97.65,208)$ & $187.2(101.4,223.0)$ & $\begin{array}{l}0.683 \text { (Non- } \\
\text { parametric) }\end{array}$ \\
\hline Urine magnesium (mmol/24h) & $3.3(2.17,4.06)$ & $2.7(2.19,3.50)$ & $\begin{array}{l}0.486 \text { (Non- } \\
\text { parametric) }\end{array}$ \\
\hline L1-L4 (g/ $\left.\mathrm{cm}^{2}\right)$ & $0.787 \pm 0.195$ & $0.863 \pm 0.187$ & 0.214 \\
\hline Femoral neck $\left(\mathrm{g} / \mathrm{cm}^{2}\right)$ & $0.604 \pm 0.163$ & $0.719 \pm 0.129$ & 0.023 \\
\hline Total hip $\left(\mathrm{g} / \mathrm{cm}^{2}\right)$ & $0.604 \pm 0.159$ & $0.756 \pm 0.128$ & 0.002 \\
\hline Fracture (with/without) & $12 / 16$ & $4 / 22$ & 0.038 (Fisher) \\
\hline Kidney stones (with/without) & $11 / 17$ & $5 / 21$ & $0.107\left(x^{2}\right)$ \\
\hline Osteoporosis at any site $(n, \%)$ & $19(67 \%)$ & $9(34 \%)$ & $0.015\left(x^{2}\right)$ \\
\hline
\end{tabular}


Table 4 Comparison of bone mineral density between male patients in the renal tubular acidification dysfunction group and the normal function group $(X \pm S)$

\begin{tabular}{|c|c|c|c|}
\hline & $\begin{array}{l}\text { Distal renal tubular dysfunction group } \\
\text { (13) }\end{array}$ & $\begin{array}{l}\text { Distal renal tubular normal group } \\
\text { (8) }\end{array}$ & $\mathbf{P}$ \\
\hline Age, y & $63.5 \pm 8.7$ & $54.25 \pm 13.7$ & 0.081 \\
\hline BMI $\left(\mathrm{kg} / \mathrm{m}^{2}\right)$ & $24.94 \pm 4.2$ & $26.51 \pm 3.09$ & 0.373 \\
\hline Albumin, $g / L$ & $42.25 \pm 3.30$ & $41.75 \pm 3.49$ & 0.750 \\
\hline $\begin{array}{l}\text { Albumin-corrected serum calcium, } \\
\mathrm{mmol} / \mathrm{L}\end{array}$ & $2.80 \pm 0.32$ & $2.79 \pm 0.34$ & 0.968 \\
\hline Serum phosphate, $\mathrm{mmol} / \mathrm{L}$ & $0.66 \pm 0.13$ & $0.72 \pm 0.17$ & 0.402 \\
\hline PTH (pmol/L) & $54.15(25.2,112.75)$ & $41.25(15.52,62.8)$ & $\begin{array}{l}0.217 \text { (Non- } \\
\text { parametric) }\end{array}$ \\
\hline 25OHD (nmol/L) & $40.05(20.0,48.1)$ & $31.4(23.8,32.4)$ & $\begin{array}{l}0.554 \text { (Non- } \\
\text { parametric) }\end{array}$ \\
\hline Serum sodium (mmol/L) & $141.9 \pm 1.28$ & $141.85 \pm 1.95$ & 0.957 \\
\hline Serum magnesium (mmol/L) & $0.87 \pm 0.07$ & $0.86 \pm 0.07$ & 0.866 \\
\hline Urinary calcium, mmol/24h & $9.07 \pm 3.83$ & $9.23 \pm 6.37$ & 0.944 \\
\hline Urinary phosphate, $\mathrm{mmol} / 24 \mathrm{~h}$ & $20.56 \pm 9.25$ & $23.28 \pm 5.99$ & 0.473 \\
\hline Urine sodium (mmol/24h) & $110.61(68.41,183.39)$ & $209.8(141.18,259.26)$ & $\begin{array}{l}0.093 \text { (Non- } \\
\text { parametric) }\end{array}$ \\
\hline Urine magnesium (mmol/24h) & $2.12(1.52,3.49)$ & $2.82(2.23,4.39)$ & $\begin{array}{l}0.258 \text { (Non- } \\
\text { parametric) }\end{array}$ \\
\hline L1-L4 (g/ $\left./ \mathrm{cm}^{2}\right)$ & $1.004 \pm 0.165$ & $1.076 \pm 0.213$ & 0.441 \\
\hline Femoral neck $\left(\mathrm{g} / \mathrm{cm}^{2}\right)$ & $0.797 \pm 0.118$ & $0.781 \pm 0.133$ & 0.798 \\
\hline Total hip $\left(\mathrm{g} / \mathrm{cm}^{2}\right)$ & $0.823 \pm 0.134$ & $0.835 \pm 0.163$ & 0.870 \\
\hline Kidney stones (with/without) & $3 / 10$ & $2 / 6$ & 1.000 (Fisher) \\
\hline Fracture (with/without) & $8 / 5$ & $7 / 1$ & 0.336 (Fisher) \\
\hline Osteoporosis at any site(n,\%) & $3(23 \%)$ & $1(12.5 \%)$ & 0.549 (Fisher) \\
\hline
\end{tabular}

So we carried out this retrospective study try to find whether the dysfunction of renal tubular acidification may affect the PHPT patients' outcomes. The cut-off rate we used to define acidification function is from our lab. We found about half of the PHPT patients (54.6\%) had distal renal tubular acidification dysfunction. Although the impaired titratable acid and ammonia ion secretion in the distal renal tubules did not cause body acid-base imbalance, we found that total hip bone density was significantly decreased in the patients with this abnormal acidification. Stratification according to gender showed that female patients with abnormal distal tubular acidification function had lower femur neck and total hip BMD and were more susceptible to bone fracture compared to those in the normal function group. However, there were no such differences in male patients between the two groups. Castellano et al. [14, 15] reported that sex and menopausal status may affect the clinical presentations of PHPT. They found that postmenopausal female PHPT patients were more prone to osteoporosis compared with male patients. Cheng et al. [16] reported that sex and age can modify skeletal manifestations in an experimental model of hyperparathyroidism, and found that high PTH levels reduced trabecular bone mass in female mice but had the opposite effect in male mice. Our results were consistent with these studies, in the condition of increasing acid loading, female PHPT patients appeared to have increased susceptibility to osteoporosis and bone fracture.

With the exception of serum phosphate and plasma 25OHD levels, serum calcium, alkaline phosphatase, $\mathrm{PTH}$, bone turnover indices and electrolyte in urine were similar between the groups with and without acidification disorders. Therefore, we speculated that decreased secretion of acid in the distal renal tubular may directly affect bone mass.

The pathogenesis of distal renal tubular acidification dysfunction in PHPT patients is not clear. It has been suggested that hypercalciuric renal tubular damage may induce dysfunction of the distal renal tubular epithelium $[6,12]$. However, we found no significant differences in urinary calcium levels between the groups with and without acidification dysfunction in the present study. Other groups have suggested that the long duration of the disease is responsible for renal interstitial calcification, which causes tubular acidification 
dysfunction [6, 11]. However, we found no correlation between acidification dysfunction and the duration of the disease. Further studies are required to determine the mechanism underlying distal renal tubular acidification dysfunction in PHPT.

\section{Conclusion}

In summary, our study found PHPT patients with abnormal distal renal tubular acidification may have lower hip bone density. Female PHPT patients with distal renal tubular acidification dysfunction showed increased susceptibility to fractures and the development of osteoporosis.

Our study is a real-world study, it is retrospectively analysis the data from the hospitalized patients. The test to evaluate the renal tubular acidification has been used in the Nephrology Department of our hospital for more than 20 years. However this method is not standardized and wildly accepted. The relatively small- scale of this study may affect its strength. So further larger scale and multi-center study are needed to confirm our findings.

\section{Abbreviations}

25OHD: 25 hydroxyvitamin D; PHPT: Primary hyperparathyroidism; PTH: Parathyroid hormone; BMD: Bone mineral density; AKP: Alkaline phosphatase; TA: Titratable acid; OC: Osteocalcin; CTX: Type I collagen crosslinked C-telopeptide; PINP: Procollagen type I N-terminal propeptide

\section{Acknowledgements}

The authors would thank the colleagues in the Endocrinology and Metabolism Disease Department who are responsible for diagnosis and treatment of hyperparathyroidism patients.

\section{Authors' contributions}

HWJ, BPW, and CLD conceived and devised the study. WNT, YC, TL and HW collected the data and WNT analyzed the data. All authors contributed to the interpretation of the data. WNT drafted the article, and all authors reviewed and edited the manuscript, approved the version to be published and agreed to be accountable for all aspects of the work. WNT and CLD accept full responsibility for the work and the conduct of the study, had access to the data, and controlled the decision to publish it.

\section{Funding}

None.

\section{Availability of data and materials}

The datasets used and/or analysed during the current study available from the corresponding author on reasonable request.

\section{Ethics approval and consent to participate}

This is a retrospective study based on data collected from the Endocrinology and Metabolism Disease Department of TJMUG Hospital. The paper was reported after the approval of Institutional Review Board (IRB)/Ethical Committee of TJMUG Hospital.

\section{Consent for publication}

Not applicable.

\section{Competing interests}

The authors declare that they have no competing interests.
Received: 24 May 2020 Accepted: 4 January 2021

Published online: 12 January 2021

\section{References}

1. Domrongkitchaiporn S, Pongsakul C, Stitchantrakul W, Sirikulchayanonta V, Ongphiphadhanakul B, Radinahamed P, Karnsombut P, Kunkitti N, Ruangraksa C, Rajatanavin $\mathrm{R}$. Bone mineral density and histology in distal renal tubular acidosis. Kidney Int. 2001;59(3):1086-93.

2. Evan AP, Lingeman J, Coe F, Shao Y, Miller N, Matlaga B, Phillips C, Sommer A, Worcester E. Renal histopathology of stone-forming patients with distal renal tubular acidosis. Kidney Int. 2007;71(8):795-801.

3. Weger W, Kotanko P, Weger M, Deutschmann H, Skrabal F. Prevalence and characterization of renal tubular acidosis in patients with osteopenia and osteoporosis and in non-porotic controls. Nephrol Dial Transplant. 2000; 15(7):975-80.

4. Sromicki JJ, Hess B. Abnormal distal renal tubular acidification in patients with low bone mass: prevalence and impact of alkali treatment. Urolithiasis. 2017:45(3):263-9.

5. Muthukrishnan J, Hari Kumar KV, Jha R, Jha S, Modi KD. Distal renal tubular acidosis due to primary hyperparathyroidism. Endocr Pract. 2008;14(9):11336.

6. Arruda JA, Kurtzman NA. Hyperparathyroidism and metabolic acidosis: a complex interaction of multiple factors. Nephron. 1980;26(1):1-6.

7. Rodriguez Soriano J. Renal tubular acidosis: the clinical entity. J Am Soc Nephrol. 2002;13(8):2160-70.

8. Guidelines for the diagnosis and treatment of primary hyperparathyroidism. Chinese journal of osteoporosis bone mineral disease. 2014;7(3):187-98.

9. Khwaja A. KDIGO clinical practice guidelines for acute kidney injury. Nephron Clin Pract. 2012;120(4):c179-184.

10. Kanis JA, McCloskey EV, Johansson H, Oden A, Melton LJ 3rd, Khaltaev N. A reference standard for the description of osteoporosis. Bone. 2008;42(3): 467-75.

11. WEGER.M DEUTSCHMANNHA, WEGER.W, KOTANKO.P, DEUTSCHMANNM. J SF: Search for occult secondary osteoporosis:impact of identifified possible risk factors on bone mineral density. J Intern Med. 2002;252(5):389-97.

12. Balwani MR, Pasari $A$, Meshram A, Jawahirani A, Tolani $P$, Laharwani $H$, Bawankule C. An initial evaluation of hypokalemia turned out distal renal tubular acidosis secondary to parathyroid adenoma. Saudi J Kidney Dis Transpl. 2018;29(5):1216-9.

13. Lo TE, Tan IT: Distal renal tubular acidosis in primary hyperparathyroidism. BMJ Case Rep 2015, 2015.

14. Castellano E, Attanasio R, Boriano A, Borretta G. Clinical Presentation of Primary Hyperparathyroidism in Older Adults. J Endocr Soc. 2019;3(12):230512.

15. Castellano E, Attanasio R, Boriano A, Pellegrino M, Garino F, Gianotti L, Borretta G. Sex Difference in the Clinical Presentation of Primary Hyperparathyroidism: Influence of Menopausal Status. J Clin Endocrinol Metab. 2017:102(11):4148-52

16. Cheng Z, Liang N, Chen TH, Li A, Santa Maria C, You M, Ho H, Song F, Bikle D, Tu C, et al. Sex and age modify biochemical and skeletal manifestations of chronic hyperparathyroidism by altering target organ responses to Ca2 + and parathyroid hormone in mice. J Bone Miner Res. 2013;28(5):1087-100.

\section{Publisher's Note}

Springer Nature remains neutral with regard to jurisdictional claims in published maps and institutional affiliations.
Ready to submit your research? Choose BMC and benefit from:
- fast, convenient online submission
- thorough peer review by experienced researchers in your field
- rapid publication on acceptance
- support for research data, including large and complex data types
- gold Open Access which fosters wider collaboration and increased citations
- maximum visibility for your research: over $100 \mathrm{M}$ website views per year
At $\mathrm{BMC}$, research is always in progress.
Learn more biomedcentral.com/submissions 